NBER WORKING PAPER SERIES

\title{
TRADE AND THE TRANSMISSION \\ OF TECHNOLOGY
}

\author{
Wolfgang Keller
}

Working Paper 6113

\section{NATIONAL BUREAU OF ECONOMIC RESEARCH 1050 Massachusetts Avenue \\ Cambridge, MA 02138 \\ July 1997}

\begin{abstract}
An earlier version of this paper circulated under the title: "International R\&D Spillover and Intersectoral Trade Flows: Do they Match?". Thanks are due to seminar audiences at ColoradoBoulder, the 1995 NBER Summer Institute, Purdue, Wisconsin-Madison, and Yale, especially Robert Evenson, Zvi Griliches, James Harrigan, Keith Maskus, F. M. Scherer, T. N. Srinivasan, Marie Thursby, and an anonymous referee. Thanks also to Christian Langer for providing the data on trade flows, to Michael Craw for the US import input-output data, and to Jonathan Putnam for his help in obtaining the technology flow matrix used in the paper. This paper is part of NBER's research programs in International Trade and Investment and Productivity. Any opinions expressed are those of the author and not those of the National Bureau of Economic Research.
\end{abstract}

(C) 1997 by Wolfgang Keller. All rights reserved. Short sections of text, not to exceed two paragraphs, may be quoted without explicit permission provided that full credit, including $\odot$ notice, is given to the source. 
Trade and the Transmission of Technology

Wolfgang Keller

NBER Working Paper No. 6113

July 1997

JEL Nos. O3, O4, F12, F2

International Trade and Investment

and Productivity

\begin{abstract}
We present a model of R\&D-driven growth which predicts that technology, in the form of product designs and created through R\&D investments, is transmitted to other domestic and foreign sectors by being embodied in differentiated intermediate goods. Empirical results are presented employing data from thirteen manufacturing industries in eight OECD countries over the period of 1970 to 1991.

We confirm, first, earlier findings that $R \& D$ expenditures are positively related to productivity levels, and estimate an elasticity of TFP with respect to own-industry R\&D between $7 \%$ and $17 \%$. Second, the receiving industry benefits also from other industries' technology investments, an effect which is at least in part due to trade in embodied technology. We find that the benefit derived from foreign R\&D in the same industry is in the order of $50 \%-95 \%$ of the productivity effect of own R\&D. Third, for domestic interindustry technology flows, the results strongly suggest that trade in goods is not all that matters for technology transmission. We estimate that domestic, outside-industry R\&D is one-fifth to one-half as effective in raising productivity as own-industry R\&D for these industries.
\end{abstract}

\author{
Wolfgang Keller \\ Department of Economics \\ University of Wisconsin \\ 1180 Observatory Drive \\ Madison, WI 53706 \\ and NBER \\ wkeller@ssc.wisc.edu
}




\section{Introduction}

The question of whether goods trade contributes to the transmission of new technologies is both old and new. It is an old question in the context of closed-economy studies that have examined whether investments in research and development $(R \& D)$ in one industry affect productivity in other industries, where these other industries are often identified through input-output relations. In these studies, trade is viewed as a channel of transmission for newly created technologies (see Griliches 1984, and, more recently, Nadiri 1993). In the open-economy context, the idea that trade might be contributing to the international transmission of technology has been emphasized only in the recent growth theory literature (Rivera-Batiz and Romer 1991, Grossman and Helpman 1991).

For a long time, there was no consensus on the question of why, on average, outward-oriented economies tend to grow more rapidly (see, e.g., World Bank 1987, Rodrik 1995). The crux of the debate centered around two important developments in the literature. First, models built within the framework of static trade with competitive markets predicted gains from trade which were very small, in comparison to real-world differences in productivity growth between the average open country and the average protectionist country. Once models capable of 
generating positive productivity growth rates even in the long-run (e.g., Romer 1990), however, were placed into an open-economy context, changes in the trade regime could have both long-run and large growth effects, and this possibility seemed to allow for a reconciliation between theory and empirics.

Secondly, there was the dissension of views on the mechanism by which trade contributes to productivity growth. According to one view, trade affects a country's growth rate through its effects on domestic resource allocation. Equating the growth effects of trade to those which are generated by changes in the domestic resource allocation, however, met with the troubling implication that a purely domestic tax-and-subsidy policy can achieve exactly what trade achieves. An alternative view, arising from the growth literature, suggested that international trade directly affects productivity growth because trade is a mechanism through which technological knowledge is transmitted internationally. In the models of growth in an open-economy, $R \& D$ investments create new technology in the form of construction designs for new intermediate products (Romer 1990; see also Ethier 1982). These products, traded internationally, benefit the recipient country that employs the new intermediate goods because that country need not first invent the construction designs. Importing a foreign intermediate good, therefore, allows 
a country to capture the R\&D-, or 'technology-content' of the good. For a given primary resources, productivity is increasing in the range of different intermediate goods which are employed, due to the assumption that they are imperfect substitutes for each other. The model predicts that total factor productivity (TFP) is positively affected by the country's own $R \& D$, as well as by $R \& D$ investments made by trade partners.

This framework is clearly also relevant to the process of technology transmission between different sectors within one economy. In this sense, the openeconomy model could well serve as a theoretical underpinning of the empirical analyses in the closed-economy studies referred to above. This paper provides a unified approach of analyzing the importance of trade for the transmission of technology, both internationally as well as domestically.

Of course, technology need not flow exclusively from the seller to the buyer. Mansfield (1984), e.g., points to evidence that technology is also transferred from the downstream to the upstream industry. Technology flows can also be disproportional to goods trade, as in the case of reverse-engineering, or not at all related to goods trade, as in the case of attending a conference where state-of-the-art technology is being demonstrated. Hence, while the model where all technology 
diffusion is based on market transactions is a useful benchmark, the answer to the question of how technology is transmitted from one sector to another is more complex than simply given by the input-output structure of an economy. This point has been recognized in both the trade and growth as well as the R\&D-TFP growth literature, ${ }^{1}$ and the analysis below accounts for that.

The importance of input-output relations in the transmission of technology in a domestic context has been emphasized by Terleckyj (1974) and, among the more recent papers, by Wolff and Nadiri $(1993) .{ }^{2}$ The analysis presented below builds on these contributions. Another strand of literature, including Scherer (1984), Jaffe (1986), Evenson et al. (1991), and Branstetter (1996), goes beyond modeling technology diffusion based on input-output market-transactions. In the contributions by Jaffe (1986) and Branstetter (1996), the authors identify the direction of technology flows between firms by differences in their patent portfolios: the more similar these are, the more likely it is that $R \& D$ in one firm affects the productivity of another. Scherer (1984) and Evenson et al. (1991) have modeled the structure of inter-industry technology diffusion by creating technology flow

\footnotetext{
${ }^{1}$ See Grossman and Helpman (1991), Ch.6.5, and Scherer (1984), respectively.

${ }^{2}$ See also Griliches (1979), in particular for a discussion of the older literature in the closedeconomy context, and the papers in Griliches (1984).
} 
matrices which predict the $R \& D$ originating from as well as the $R \& D$ used by a given sector. Below we will employ a technology flow matrix based on the work of Evenson et al. (1991).

Coe and Helpman (1995), Coe et al. (1995), Englander et al. (1995), and Park (1995) have recently presented evidence on how trade contributes to the international diffusion of $R \& D$ spillovers. ${ }^{3}$ Although motivated by recent theories of trade and long-run growth, their empirical analysis is very much in the spirit of the papers by Terleckyj, Griliches, and Scherer. Coe and Helpman use countrylevel data to show that countries' productivity levels are positively affected by domestic as well as bilateral import-share weighted foreign R\&D stocks; hence, the import shares take the place of input coefficients in the domestic TFP-R\&D literature.

The present paper departs from earlier work in several respects: First, we use industry-level data on international transactions, as opposed to the country-level data employed by Coe and Helpman (1995), Coe et al. (1995), and Park (1995). It has been argued that studies employing aggregate data are likely to miss much of the technology flows, because the diversity of sectoral characteristics as well as

\footnotetext{
${ }^{3}$ See also Eaton and Kortum (1996).
} 
the very nature of technology diffusion tends to confound any inferences which can be made from that data (e.g., Branstetter 1996). The use of two- or three-digit industry level data should reduce this problem. Secondly, this paper integrates the recent emphasis on the open-economy relations with earlier work, in particular by Terleckyj (1974), Scherer (1984), and Evenson et al. (1991), which stressed the dimension of domestic intersectoral technology transmission. The advantage of this approach is that all transactions predicted by the theoretical model, both domestic as well as international are considered, in contrast to earlier studies which have focused on only a subset of those.

Third, in the model of technology diffusion presented below, we can derive the specific form of the model's prediction on how outside R\&D should matter for productivity. Therefore, we are able to test whether new technology created in the industry of a particular country has the same productivity effects as new technology from other domestic sectors, from abroad, or from other sectors in other countries. This should improve our understanding of the way and extent to which trade is related to the transmission of technology.

The remainder of the paper is as follows. In the next section, we describe the R\&D-driven growth and intermediate inputs model. Section 3 gives an account 
of the data which will be used. Section 4 gives the estimation results, and section 5 concludes.

\section{R\&D-Driven Growth and Intermediate Inputs Trade}

We consider a typical model of the Ethier-Romer, Grossman and Helpman variety, in which long-run growth is endogenously driven by $R \& D$ investments, and technology is being transmitted via trade in intermediate inputs.

\subsection{Domestic Intersectoral Trade}

Assume that good $z_{j}$ in sector $j, j=1, \ldots, J$, is produced according to

$$
z_{j}=A_{j} l_{j}^{\alpha} d_{j}^{1-\alpha}
$$

where $A_{j}$ is a constant, $l_{j}$ are labor services used in final output production, and $d_{j}$ is a composite input consisting of horizontally differentiated goods $x$ of variety $s$. Specifically, $d_{j}$ is given by

$$
d_{j}=\left(\int_{0}^{n_{j}^{\text {de }}} x_{j}(s)^{1-\alpha} d s\right)^{\frac{1}{1-\alpha}}
$$


The variable $n_{j}^{d e}$ denotes the range of intermediate inputs which are employed in this sector (ignoring integer constraints). Here, the superscript $d$ stands for domestic, and $e$ stands for employed. We distinguish $n_{j}^{d e}$ from $n_{j}^{p}$, the range of intermediate inputs produced in sector $j$; the latter is increased by entrepreneurs devoting resources to $R \& D$. Denote with $\phi_{j}^{p}$ the flow of $R \& D$ expenditures in sector $j$. Blueprints of new inputs are simply created according to $\dot{n}_{j}^{p}=\phi_{j}^{p}$. These resources could be in form of labor services which have an alternative use in the output sector. ${ }^{4}$ If designs never become obsolete, the stock of intermediate inputs produced in sector $j$ at time $T$ is equal to $n_{j}^{p}(T)=\int_{-\infty}^{T} \dot{n}_{j}^{p}(t) d t=\int_{-\infty}^{T} \phi_{j}^{p}(t) d t$, that is, equal to the cumulative $R \& D$ resources at time $T$; we define $n_{j}^{p}(T) \equiv b_{j}(T)$.

We assume that to produce one unit of any intermediate good requires one unit of sectoral output. Then, if capital $k_{j}$ is defined as cumulative foregone sectoral output, this will be equal to $k_{j}=\int_{0}^{n_{j}^{p}} x_{j}(s) d s$. In a symmetric equilibrium, all intermediates $x$ are produced at the same level, so that $k_{j}=n_{j}^{p} x_{j}$. Rearranging

\footnotetext{
${ }^{4}$ This presentation does not account for those; see, e.g., Romer (1990) for a complete description.
} 
for $x$, and substituting into (2.2) leads to the following expression for output ${ }^{5}$

$$
z_{j}=A_{j}^{\prime}\left(n_{j}^{d e}\right)^{\alpha} l_{j}^{\alpha} k_{j}^{1-\alpha},
$$

Defining an index of TFP, $f_{j}^{*}$, as $f_{j}^{*}=\frac{z_{j}}{l_{j}^{\alpha} k_{j}^{j-\alpha}}$, and taking logs results in

$$
\log f_{j}^{*}=\log A_{j}^{\prime}+\alpha \log n_{j}^{d e} .
$$

Note that in equation (2.3), $f^{*}$ is positively related not to the range of intermediates which have been invented in sector $j\left(n_{j}^{p}\right)$, but to those which are employed there $\left(n_{j}^{d e}\right)$. We model the range of intermediates employed as the weighted sum of the ranges of intermediates of all sectors, where the weights are given by the input-output relations of the sectors ${ }^{6}$

$$
n_{j}^{d e}=n_{j}^{p}+\sum_{v \neq j}^{J} \omega_{j v} n_{v}^{p}, \forall j
$$

Let $\Omega$ be the matrix of observed input-output coefficients, with a typical element

\footnotetext{
${ }^{5}$ Here, $A_{j}^{\prime}=A_{j}\left(n_{j}^{d e} / n_{j}^{p}\right)^{1-\alpha}$. In the following, the term $\left(n_{j}^{d e} / n_{j}^{p}\right)^{1-\alpha}$ will be ignored, expecting that this will not crucially affect the estimation below.

${ }^{6}$ See Terleckyj (1974); the origin of the idea to model R\&D spillovers as the weighted sum of other sector's R\&D is Griliches (1979).
} 
$\omega_{j v}$

$$
\boldsymbol{\Omega}=\left[\begin{array}{cccc}
0 & \omega_{j v} & \omega_{j w} & \cdots \\
\omega_{v j} & 0 & \vdots & \vdots \\
\vdots & \vdots & \ddots & \vdots \\
\cdots & \cdots & \cdots & \ddots
\end{array}\right]
$$

In terms of observables, this means that the effective domestic R\&D stock which affects TFP in sector $j$ is

$$
b_{j}^{d e}=b_{j}+\Omega_{j} \mathbf{b}_{v}, v \neq j, \forall j
$$

Here, $\Omega_{j}$, of dimension $(1 \times J)$, is the $j$ th row of $\Omega$, and $\mathbf{b}_{v}$ is of dimension $(J \times 1)$. Hence, $b_{j}^{d e}$ is an input-output weighted sum of the cumulative R\&D stocks of all sectors $v$. For a given sector $j$, denote the R\&D effect from other sectors by $b_{j}^{i o}$. With this notation, we have that

$$
\log f_{j}^{*}=\log A_{j}^{\prime}+\alpha \log b_{j}^{d e}=\log A_{j}^{\prime}+\alpha \log \left(b_{j}+b_{j}^{i o}\right), \forall j .
$$




\subsection{International Intra-Industry and Inter-Industry Trade}

When there is more than one country, output producers in country $i$ 's sector $j$ can employ intermediates from other countries $h$ in addition to those from other domestic sectors, $v \neq j{ }^{7}$ The effects of intermediate goods from the same sectors in other countries and from other sectors in other countries can be treated analogously. First, we consider international intra-industry trade. Coe and Helpman (1995) have recently proposed to model the effect of foreign R\&D on domestic productivity by utilizing bilateral import shares as weights. These are conceptually identical to the input-output relations capturing domestic trade transactions. Let $m_{i h j}$ be the bilateral import share of country $i$ from country $h$ for industry $j$. For a given country and sector $i j$, the effect from foreign intermediates produced

\footnotetext{
${ }^{7}$ This will happen in equilibrium. Analytic results for the symmetric two-country case are derived, e.g., in Keller (1996).
} 
in the same industry, $b_{i j}^{f}$, is then ${ }^{8}$

$$
b_{i j}^{f}=\sum_{h \neq i}^{I} m_{i h j} b_{h j}, \forall i j .
$$

The domestic sector $j$ can also employ intermediate inputs from foreign sectors $v \neq j$, and therefore benefit from technology created there. The matrix which captures those market relations is the input-output matrix for imports. Let $\gamma_{i j v}$ denote the share of country $i$ 's imports of the $j$ intermediate which go to the $v$ industry, where $i=1, \ldots, I$, and $j, v=1, \ldots, J$. Then, define $b_{i j}^{f, i o}$ as the R\&D effect from foreign intermediates in industries other than $j$,

$$
b_{i j}^{f, i o}=\sum_{v \neq j}^{J} \gamma_{i j v} b_{i v}^{f}, \forall i, j
$$

\footnotetext{
${ }^{8}$ So far, we have considered the contemporaneous relation between R\&D stocks and TFP. It is clear, however, that R\&D outlays must precede productivity effects because of the presence of various lags in the invention and commercialization process, see, e.g., Pakes and Schankerman (1984). These authors argue that the mean lag should be in the range of 1.2 to 2.5 years, p.84. Of particular interest is here whether foreign $R \& D$ influences domestic productivity with the same mean lag as domestic R\&D, or whether this lag is perhaps longer. While data availability precludes estimation of the precise lag structures for domestic and foreign $R \& D$, we present some results in Table A.7 of the appendix for the case where the relation between TFP and domestic $R \& D$ is contemporaneous, whereas with foreign $R \& D$, there is a one-year lag. These results are discussed below.
} 
If we allow the productivity effects through intermediate inputs from different sources to differ, then a TFP index analogous to (2.5) can be written as

$$
\log f_{i j}^{\prime}=\mu_{i j}+\beta_{1} \log \left(b_{i j}+\beta_{2} b_{i j}^{i o}+\beta_{3} b_{i j}^{f}+\beta_{4} b_{i j}^{f, i o}\right)+\varepsilon_{i j}, \forall i, j
$$

where the error term $\varepsilon_{i j}$ is assumed to be mean zero and independently and normally distributed, capturing all influences to the relation of R\&D and TFP which are not modeled. If trade plays no role for the transmission of technologyembodied in intermediate inputs - then only own-industry $R \& D$ will be significantly correlated with TFP, and $\beta_{2}, \beta_{3}$, and $\beta_{4}$ will be equal to zero. Another interesting hypothesis is that domestic, other industry as well as foreign, and foreign, other industry $R \& D$ have the same effect as own $R \& D$ expenditures, in which case $\beta_{2}, \beta_{3}$, and $\beta_{4}$ will equal one.

\subsection{Capturing Intersectoral Technology Flows Beyond Input-Output Relations}

We have given above several reasons why intersectoral trade relations might only account for a part of technology diffusion between sectors. Scherer (1984) and

Evenson et al. (1991) in particular are among those who have gone beyond relating 
intersectoral technology flows to intersectoral trade alone. Both studies estimate a technology flow matrix, denoted with TM,

$$
\mathbf{T M}=\left[\begin{array}{cccc}
\pi_{j j} & \pi_{j v} & \pi_{j w} & \cdots \\
\pi_{v j} & \pi_{v v} & \vdots & \vdots \\
\vdots & \vdots & \ddots & \vdots \\
\cdots & \ldots & \ldots & \ddots
\end{array}\right]
$$

A typical element $\pi_{j v}$ indicates to what extent the R\&D conducted in sector $j$ is used in sector $v$. In this approach, the entries for any row $j$ sum to one, i.e., $\sum_{j} \pi_{v j}=1, \forall v$; this includes the R\&D which is both conducted and used in sector $v$, that is, the elements on the main diagonal of (2.9). We are primarily interested in using the technology flow matrix as an alternative to the input-output matrix $\Omega$ in capturing intersectoral technology diffusion between sectors, and therefore set the main diagonal in TM to zero. The magnitude of the off-diagonal elements in the matrix $T M$ then indicates to what extent the $R \& D$ results of a row industry $v$ are beneficial to another column industry $j^{9} \quad$ Let $b_{i j}^{t m}$ and $b_{i j}^{f, t m}$ denote the

\footnotetext{
${ }^{9}$ The fact that any row in TM sums to one implies a private goods-notion of R\&D, because any R\&D dollar spent in industry $j$ can only allocated to one particular industry (including own industry); this differs from the public goods nature of the production designs in, e.g., a Romer (1990)-type model. However, this issue is well-recognized; see Scherer (1984), pp. 432-5 for a
} 
domestic, other industry, and the foreign, other industry R\&D variable, which are computed in analogy to $b_{i j}^{i o}$ and $b_{i j}^{f, i o}$, respectively, by replacing the input-output matrix, and the import input-output matrix, respectively, with the technology flow matrix TM. The technology flow-based specification is then given by

$$
\log f_{i j}=\mu_{i j}+\beta_{1} \log \left(b_{i j}+\beta_{2} b_{i j}^{t m}+\beta_{3} b_{i j}^{f}+\beta_{4} b_{i j}^{f, t m}\right)+\varepsilon_{i j}, \forall i, j .
$$

With equation (2.10), it is implicitly assumed that the general form of how outside industry R\&D matters for productivity is the same as in the model of technology diffusion through intermediate inputs trade, and that technology diffusion beyond intermediate inputs trade is appropriately captured by substituting $b^{t m}$ and $b^{f, t m}$ for $b^{i o}$ and $b^{f, i o}$, respectively.

We now turn to describing the basic characteristics of the data.

\section{Data}

This paper uses data for eight OECD countries for the years 1970-1991 (for more details on data sources and construction, see the appendix). The countries are

discussion. For our empirical purposes, the issue is not central; what matters is that the offdiagonal elements in a given row capture the relative extent to which column industries benefit from the row industry's $R \& D$. 
Canada, France, Germany, Italy, Japan, Sweden, the United Kingdom, and the United States, hence, the G-7 group plus Sweden. We use an industry classification with thirteen two- to three-digit manufacturing industries according to the UN International Standard Industrial Classification (ISIC)..$^{10}$ A TFP (index) is constructed using the Structural Analysis industrial (STAN) database of the OECD (1994) by first calculating the growth of TFP as the difference between output and factor-cost share weighted input growth. Then, the level of TFP is normalized to 100 in 1970 for each of the $8 \times 13$ time series. In Table A.1, summary statistics on the TFP data are shown.

As defined above, the unobservable technology stock variable $n$ is identified with the sectoral cumulative R\&D stocks, derived from OECD (1991) data on private $R \& D$ expenditures. ${ }^{11}$ This data covers all intramural business enterprise expenditures. Summary statistics on this data are given in Table A.2. The R\&D

\footnotetext{
${ }^{10}$ These are: (1) ISIC (adjusted revision 2) 31 Food, beverages, and tobacco; (2) ISIC 32 Textiles, apparel, and leather; (3) ISIC 33 Wood products and furniture; (4) ISIC 34 Paper, paper products and printing; (5) ISIC $351+352$ Chemicals and drugs; (6) ISIC $353+354$ Petroleum refineries and products; (7) ISIC $355+356$ Rubber and plastic products; (8) ISIC 36 Non-metallic mineral products; (9) ISIC 37 Basic metal industries; (10) ISIC 381 Metal products; (11) ISIC $382+385$ Non-electrical machinery, office and computing equipment, and professional goods; (12) ISIC 383 Electrical machines and communication equipment; and (13) ISIC 384 Transportation equipment.

${ }^{11}$ We assume a rate of knowledge depreciation, $\delta$, of $10 \%$, which is typical in this literature (Nadiri and Prucha 1993). This is contrary to the model above, where $\delta=0$. In Table A.7, we show results based on alternative assumptions on $\delta$, which are discussed below.
} 
stocks are derived from the $R \& D$ expenditure series using the perpetual inventory method.

Constructing the import-weighted foreign R\&D capital stocks as described above requires data on bilateral import flows. These are obtained from the World Trade Data Base of the Hamburg Institute of Economic Research (HWWA). It is clear from the construction of the $b^{f}$ variables that the origin of a given country's imports (together with the R\&D efforts there) determines the size of the foreign $\mathrm{R} \& \mathrm{D}$ variable of the importing domestic industry. In Tables A.3-1 and A.3-2, a subset of these bilateral import shares by sector are shown for sectors ISIC 31 and ISIC 384.

We employ the input-output matrix of the U.S. economy for all countries in the sample. It is derived from the benchmark input-output Table 2 published in U.S. Department of Commerce (1991). The $13 \times 13$ matrix of input-output coefficients can be found in Table A.4. The input-output matrix for imports is also derived from U.S. data, and assumed to be the same for all countries. It is based on unpublished material of the U.S. Department of Commerce (1996) on the use of commodities by industry in the import sector. ${ }^{12}$ The $525 \times 505$ matrix is

\footnotetext{
${ }^{12}$ This data was collected in conjunction with the 1987 benchmark survey.
} 
aggregated up to the $13 \times 13$ industry classification used in this paper, and is shown in Table A.5. As can be seen from tables A.4 and A.5, to avoid double counting of own-industry $R \& D$, the own-industry effect has been eliminated by setting the main diagonals equal to zero. The technology flow matrix TM is based on the work by Evenson et al. (1991). These authors have created a concordance between the industry-of-origin and the industry-of-use of an invention, using Canadian patent data at a 4-digit SIC level..$^{13}$ Here, this matrix, called the "Yale Technology Concordance", has been aggregated up to the $13 \times 13$ industry classification used in this paper. The technology flow matrix is shown in Table A.6. ${ }^{14}$

It is important to note that the practice of data collection and preparation by the statistical agencies is such that part of the estimated spillover effect due to input-output relations is spurious, primarily because of the unavailability of deflators which fully adjust for increases in the quality of a product, or because these deflators are not continuously, but only discretely adjusted. Therefore, measured TFP in sector $j$ is affected by productivity improvements in industry

\footnotetext{
${ }^{13}$ The work by Evenson et al. (1991) is similar in spirit to the project by Scherer (1984) and his associates.

${ }^{14}$ The bilateral trade shares matrices are averaged over time (1972-91); the input-output matrix reflects the relations in the U.S. economy in the benchmark year of 1980; the import input-output matrix is for the benchmark year of 1987, and the patent classification data for the Yale Technology Concordance is from the years 1978-87.
} 
$v \neq j$ to the extent that it purchases from $v$ and that these improvements have not been incorporated in the official input price indices of industry $j .{ }^{15}$ While we do not have a way of estimating how large these effects are, and whether they are invariant across sectors and countries, the presence of these effects generally suggests that the spillovers estimates presented below should be viewed as an upper bound on the true spillover effects.

\section{Estimation Results}

There are eight countries with thirteen industries each, for the time period of 1970-91, making a total of 2288 annual observations. We allow for a generalized time trend by including a fixed effect for each year; further, a full set of 104 (8 $x$ 13) country-industry fixed effects are employed in all regressions. Rather than including these sets of dummy variables in the regression equation, the log of any variable $q, q=f, b, b^{i o}, b^{t m}, b^{f}, b^{f, i o}$, and $b^{f, t m}$ is obtained by first subtracting the year-, and then the country-industry-means from the data.

\footnotetext{
${ }^{15}$ Another important determinant of the magnitude of these measured TFP effects is the extent to which the supplying industry can appropriate the improvements in the quality of its product; see Griliches (1979) for more discussion on this.
} 


\subsection{Technology Diffusion through Goods Trade at Arm's Length}

In this section, we present results based $R \& D$ measures which capture trade in goods alone: through the input-output matrix (leading to $b^{i o}$ ), the international bilateral trade share matrix (giving the variable $b^{f}$ ), and the bilateral import share matrix together with the import input-output matrix (resulting in the variable $\left.b^{f, i o}\right)$. The specification used in the regression is given by

$$
\log f_{i j t}=\eta_{0}+\beta_{1} \log \left(b_{i j t}+\beta_{2} b_{i j t}^{i o}+\beta_{3} b_{i j t}^{f}+\beta_{4} b_{i j t}^{f, i o}\right)+\varepsilon_{i j t}, \forall i, j, t
$$

Table 1 shows the results of these estimations. The method is non-linear least squares, which simplifies to ordinary least squares (OLS) in regression (T1.1). The elasticity of TFP with respect to $\mathrm{R} \& \mathrm{D}, \beta_{1}$, is estimated to be $7.4 \%$ in regression (T1.1), significantly different from zero at a $1 \%$ level. ${ }^{16}$ When, with the $b^{i o}$ variable, the effect of $R \& D$ via domestic intermediate inputs is included, the $R \& D$ elasticity is raised to $19.4 \%$, and the estimated coefficient on $b^{i o}$ is, with 1.639 , larger than one (see T1.2). Taken at face value, this implies that domestic R\&D external to an industry has larger TFP effects than the R\&D undertaken in the

\footnotetext{
${ }^{16}$ In the tables, a parameter which is significantly different from zero at a $5 \%(10 \%)$ level is denoted with ${ }^{* *}\left({ }^{*}\right)$.
} 
industry itself. When also the foreign, same-industry $R \& D$ variable is included, in (T1.3), we obtain an estimate on $b^{f}$ which is only slightly lower than one, suggesting that foreign same-industry $R \& D$ substitutes almost perfectly for domestic R\&D in this sample of industries. Finally, regression (T1.4) gives the full specification of $(4.1)$, including the effect from foreign, other-sector $\mathrm{R} \& \mathrm{D}\left(b^{f, i o}\right)$. The effect from $R \& D$ in foreign industries outside the receiving industry is estimated to have no significant effect on domestic TFP, with a parameter estimate of -0.885 , and an estimated standard error of 0.773 . According to the full specification, the elasticity with respect to own-industry $\mathrm{R} \& \mathrm{D}$ is $21.2 \%$, the effect from domestic, different-sector $R \& D$ is more than double that $\left(\beta_{2}=2.316\right)$, and the effect from foreign, same-sector $R \& D$ through input-output channels is estimated to be very similar to domestic, same-sector $R \& D\left(\beta_{3}=1.01\right)$.

It is surprising to see that the estimate of the productivity effects of domestic outside-industry $\mathrm{R} \& \mathrm{D}, \beta_{2}$, exceeds one. This implies a very strong, and, it seems, too strong form of R\&D spillovers. According to Figure 1, the R\&D intensitydefined as $R \& D$ expenditures divided by the value of production-is smaller than three percent in all but four industries. While it is therefore possible that outsideindustry productivity effects are quite strong relative to own $R \& D$ effects, it is 
nevertheless implausible to estimate a stronger outside-industry productivity effect than the effect from own R\&D. For one, this finding stands in contrast to most of the comparable earlier studies; see the survey by Griliches (1995). For another, the fact that our sample constitutes exclusively of manufacturing industries makes the finding of $\beta_{2} \gg 1$ even less plausible: Non-manufacturing industries might benefit to a large extent from technology spillovers provided by manufacturing industries, but within a sample of manufacturing industries, the own-R\&D effect is almost certainly larger than the productivity effect from outside-industry R\&D. ${ }^{17}$ We have tried to address this issue by making various changes in the econometric specification of (4.1), by analyzing results by individual industry, and by redefining the input-output weighing matrix, without being able to fully resolve it. ${ }^{18}$ Thus we conclude that the 'pure transactions view' of intersectoral technology diffusion, as captured by the input-output matries, does not fully capture the process of intersectoral technology diffusion. In the following, therefore, a technology flow matrix is considered as an alternative to the input-output matrices.

\footnotetext{
${ }^{17}$ A similar point is made in Griliches and Lichtenberg (1984b), footnote 5.

${ }^{18}$ These results are available upon request.
} 


\subsection{Intersectoral Diffusion Captured by a Technology Flow Matrix}

In the following, we substitute the variables $b^{t m}$ and $b^{f, t m}$ for $b^{i o}$ and $b^{f, t i o}$, respectively, as shown in equation (4.1)

$$
\log f_{i j t}=\eta_{0}+\beta_{1} \log \left(b_{i j t}+\beta_{2} b_{i j t}^{t m}+\beta_{3} b_{i j t}^{f}+\beta_{4} b_{i j t}^{f, t m}\right)+\varepsilon_{i j t}, \forall i, j, t
$$

while keeping the foreign, same sector R\&D variable $b^{f}$ unchanged. The technology flow matrix on which basis the variables are constructed is derived from Evenson et al. (1991). ${ }^{19}$ Table 2 shows the results of this estimation.

The OLS regression of (T2.1) is identical to (T1.1). The specification which includes the $b^{t m}$ variable generates an estimate of $\beta_{1}=0.107$ for the domestic, ownindustry R\&D variable, and a coefficient of 0.472 for domestic, outside-industry $\mathrm{R} \& \mathrm{D}$; the latter is not precisely estimated, though, and not statistically significant at standard levels ( $\mathrm{p}$-value of 0.22 ). When the variable $b^{f}$, based on international trade in the same industry, is included, the domestic, own-industry elasticity es-

\footnotetext{
${ }^{19}$ In the spirit of Scherer (1984) and Evenson et al. (1991), the following results are based on allocating the R\&D stock of a particular sector (in a certain row of the TM matrix) fully to all using industries, including the row industry itself. That means that the own-industry R\&D variable $b_{j}$ is now scaled by the diagonal element of the technology matrix shown in Table A.6, i.e., by $\pi_{j j}$. The procedure corresponds to a private goods notion of these R\&D stock, see the discussion above. The estimation results are very similar, whether $b_{j}$ is scaled by $\pi_{j j}$ or not.
} 
timate rises to $\beta_{1}=0.171$, the domestic, outside-industry effect remains at about $50 \%$ of that $\left(\beta_{2}=0.511\right.$, again not significant at standard levels $)$, and the effect from foreign $\mathrm{R} \& \mathrm{D}$ through trade in the same industry, $b^{f}$, is estimated to be 0.952 , statistically significant at a $1 \%$ level. In regression (T2.4), also the foreign, other-industry variable $b^{f, t m}$, is included. Now, the domestic, own-industry effect is estimated to be 0.103 , and the foreign, same-industry effect $\left(\beta_{3}\right)$ is equal to 0.848. The domestic, other-industry effect is now estimated to be statistically significantly larger than zero, but it is also larger than one, with $\beta_{2}=1.24$. At the same time, the foreign, other-industry effect is estimated to be large and significantly negative, with $\beta_{4}=-1.808$. It is, however, rather difficult to think of a reason why foreign $R \& D$ in other sectors should have a large negative effect on domestic productivity; more likely, the estimate of $\beta_{4}$ picks up something else, and given that it statistically significant and large, one should in general discount the results of regression (T2.4).

It appears that, with the given approach and the data available, we cannot adequately trace the productivity effects from foreign R\&D in other sectors. ${ }^{20}$

\footnotetext{
${ }^{20}$ This might be not surprising, given that the variable $b^{f, t m}$ combines elements of the 'transactions' approach to technology diffusion, as captured in the bilateral import share matrix used to compute $b^{f}$, with a more general view of technology flows (computing $b^{f, t m}$ with the matrix TM); the two weighing matrices might not be compatible. We have experimented with an alternative foreign, other-industry variable, $\hat{b}^{f, t m}$, constructed as follows: Let $\hat{b}_{i j t}^{f} \equiv \sum_{h \neq i}^{I} b_{h j t}, \forall i, j, t$.
} 
On the plus side, employing the technology flow matrix leads to plausible estimates for the domestic, same-industry as well as the foreign, same-industry effect, and in particular for the productivity effect from domestic, other-industry $R \& D$, even though the latter is not precisely estimated. Overall, from this sample of manufacturing industries, we estimate an elasticity with respect to own-industry $\mathrm{R} \& \mathrm{D}$ of $10-17 \%$, a foreign, own-industry effect which is almost as strong as the domestic, own-industry effect, and a domestic, other-industry effect which seems to be about half the size of the own-industry effect, although it is estimated rather imprecisely,

We can formally test some interesting hypotheses. In regression (T2.3), which does not include the foreign, other-industry $\mathrm{R} \& \mathrm{D}$ stock $\left(b^{f, t m}\right)$, we cannot reject the null hypotheses that $\beta_{2}=\beta_{3}=1$ at a $5 \%$ level: a likelihood ratio test gives a statistic of 4.54 , whereas the critical value $\chi^{2}(2,5 \%)$ is equal to 5.99 . The same null hypothesis can, however, be rejected at a significance level somewhat larger than $10 \%$ (critical value $\chi^{2}(2,10 \%)=4.61$ ). Contrary to that, the null hypothesis that domestic, other-industry $R \& D$ has a productivity effect which is half the size

Then, the variable $\hat{b}^{f, t m}$ is computed by channeling $\hat{b}^{f}$ through the matrix TM. That is, we simply sum up the R\&D stocks in a given industry and year, except a given country's own $\mathrm{R} \& \mathrm{D}$, and then feed these variables through the technology flow matrix to compute the foreign, other-industry variable. However, also this variable has a large and negative coefficient. 
of own-industry, and foreign, own-industry $\mathrm{R} \& \mathrm{D}\left(H_{0}: \beta_{2}=0.5, \beta_{3}=1\right)$ is, with a likelihood ratio test statistic of 2.08 , very hard to reject. ${ }^{21}$ In that restricted regression, the own-industry $R \& D$ coefficient $\beta_{1}$ is estimated to be 0.169 . The hypothesis that domestic, other-industry R\&D has the same productivity effects as own-industry $\mathrm{R} \& \mathrm{D}\left(H_{0}: \beta_{2}=1\right)$ is, with a likelihood ratio test statistic of 3.52 , not rejected at a $5 \%$ level (critical value $\chi^{2}(1,5 \%)=3.84$ ), but at a $10 \%$ level (critical value $\left.\chi^{2}(1,10 \%)=2.71\right)$. Lastly, the hypothesis that foreign $R \& D$ in the same industry has the same productivity effects as domestic $R \& D\left(H_{0}: \beta_{3}=1\right)$ cannot be rejected even at a $10 \%$ level of significance. ${ }^{22}$

We might be able to infer more by restricting the sample to $R \& D$ intensive industries; naturally, the point estimates might differ, but because measurement and

\footnotetext{
${ }^{21}$ It is clear that we could not reject the null that $\beta_{2}=0.5$ and $\beta_{3}=0.9$, or, $\beta_{2}=0.5$ and $\beta_{3}=1.1$, either.

${ }^{22}$ In this footnote we discuss the sensitivity of the results with respect to the assumptions on the lag structure and obsolescence of technological knowledge; see Tables A.7-1 and A.7-2 in the appendix. The former includes the regressor $b^{f, t m}$, whereas the latter does not. On the lag structure issue, note that the estimation results change very little if we assume that foreign $R \& D$ has its productivity effect with a one-year lag; $\beta_{3}$ equals 0.812 with lag ( 0.848 without) in A.7-1, and 0.959 with lag (versus 0.952 without) in A.7-2. Assuming different knowledge depreciation rates makes more of a difference. Assuming $\delta=0(\delta=0.2)$ leads to a higher (lower, generally) coefficient on own $\mathrm{R} \& \mathrm{D}$, relative to assuming $\delta=0.1$. In A.7-2, the coefficient on $b^{\text {tm }}$ is higher (lower) for $\delta=0(\delta=0.2)$, relative to assuming $\delta=0.1$; with $\delta=0$, the coefficient on $b^{\text {tm }}$ is significantly positive at a $10 \%$ level, and approximately equal to the foreign, same-industry effect. For $\delta=0.2, \beta_{2}$ is essentially zero. Lastly, assuming $\delta=0$ leads to a lower estimate for the productivity effect from foreign, same-industry R\&D in A.7-2, compared to assuming $\delta=0.1$. Overall, it is clear that different assumptions on $\delta$ have, in particular for $b^{t m}$, some, but no overwhelming effect on the estimates. Below we will attempt to obtain a more precisely estimate of $\beta_{2}$ by considering only a subsample of the data.
} 
imputation errors are likely to be relatively smaller, focusing on $R \& D$ intensive industries perhaps allows to obtain more precise estimates. As seen from Figure 1, there are four industries which have a considerably higher $R \& D$ intensitydefined as $\mathrm{R} \& \mathrm{D}$ expenditures divided by the value of production- than the other sectors: Chemicals and Drugs (ISIC 351/2), Non-electrical Machinery and Precision/Optical Instruments (ISIC 382/5), Electrical Machinery (ISIC 383), and Transportation (ISIC 384). In the following section, we focus on those industries. This reduces the sample size to 704 observations. Table 3 gives the results of specification (2.10) in the restricted sample.

As regression (T3.1) shows, the own-industry R\&D elasticity is estimated to be 0.442 , about six times as large as in the full sample. Including the domestic, otherindustry variable $b^{t m}$, we estimate a coefficient of 0.192 , significant at a $10 \%$ level. Note that this implies an elasticity with respect to domestic, other-industry R\&D of $9.8 \%(0.512 \times 0.192)$, which is about double of our estimate in the full sample $(0.107 \times 0.472=5.1 \%$, regression $\mathrm{T} 2.2)$. In regression $(\mathrm{T} 3.3)$, the effect from the import-channeled foreign, same-industry $\mathrm{R} \& \mathrm{D}, b^{f}$, is included: we estimate $\beta_{1}=0.730, \beta_{2}=0.381$, and $\beta_{3}=0.577$, where all coefficients are significantly different from zero at a $1 \%$ level. Lastly, including the foreign, other-industry 
variable $b^{f, t m}$ results, as in the full sample, in a significantly negative coefficient for $\beta_{4}$, with -0.882 (see T3.4), which is hard to rationalize on a priori grounds. Although the own-industry $R \& D$ effect drops from 0.73 to 0.443 , we note that the coefficients $\beta_{2}$ and $\beta_{3}$ remain at about 0.5 of the own-industry effect.

Also in the subsample of R\&D intensive industries, we can test several hypotheses; consider regression (T3.3) which omits the $b^{f, t m}$ regressor. First, the null hypothesis $H_{0}: \beta_{2}=\beta_{3}=1$ is, with a likelihood ratio test statistic of 15.4, rejected at a $1 \%$ level (critical value $\left.\chi^{2}(2,1 \%)=10.60\right)$. Contrary to that, the null that $\beta_{2}=\beta_{3}=0.5$ is not rejected even at a $10 \%$ level (test statistic of 4.14). Second, the null hypotheses that either the domestic, other-industry effect or the foreign, same-industry effect is equally strong as the own-industry effect are both rejected at a $1 \%$ level. Contrary to that, the hypotheses that $\beta_{2}=0.5$ or $\beta_{3}=0.5$ are not rejected at a $10 \%$ level.

Comparing the results for all industries and the $R \& D$ intenstive subsample using the results of (T2.3) and (T3.3), we find, first, that the own-industry elasticity is about four times larger for $R \& D$ intensive industries than for all thirteen manufacturing industries ( 0.73 versus 0.17$)$. The finding of larger $R \& D$ elasticities for $R \& D$ intensive industries is typical in this literature (e.g., Englander et al. 1988). 
Second, the benefit from other sector's $R \& D$ is estimated to be relatively smaller for R\&D intensive industries. This holds both for domestic, other-industry R\&D as well as for foreign, same-industry $R \& D(0.38$ versus 0.51 for the former, and 0.57 versus 0.95 for the latter). This is consistent with the notion that less $R \& D$ intensive industries tend to be to a larger extent technology 'users' than industries which conduct a lot of $R \& D$ themselves.

Third, the finding that R\&D intensive industries benefit to a lesser extent from outside $R \& D$ is more pronounced for foreign, same-industry $R \& D$ than for domestic, other-industry R\&D. In the former, the benefit of $R \& D$ intensive industries from outside R\&D falls to $60 \%$ of that in the full sample, whereas it falls only to $75 \%$ of that in the full sample in the case of domestic, outside-industry R\&D. While there are many possible explanations for this finding, one might be that $R \& D$ intensive firms tend to operate in a monopolistically competitive environment, where a relatively high degree of appropriatation by the inventors leads to lower intra-industry technology spillovers.

Summarizing, for the sample of all manufacturing industries (R\&D intensive manufacturing industries), we find own-R\&D elasticities in the range of $7-17 \%$ (44-73\%). The elasticity for domestic R\&D from other industries is estimated 
to be in the range of $5-9 \%(10-27 \%)$, and we calculate an elasticity for foreign R\&D in the same industry of about $16 \%(42 \%) .{ }^{23}$ Note that the magnitude of the effects of foreign $\mathrm{R} \& \mathrm{D}$ is much larger than estimated, e.g., in Coe and Helpman (1995), who estimate a foreign R\&D elasticity of only $6 \% .^{24}$

\section{Conclusions}

A model of R\&D-driven growth has been presented which predicts that technology in form of product designs, created through $\mathrm{R} \& \mathrm{D}$ investments, is transmitted to other sectors by being embodied in differentiated intermediate goods demanded by these sectors. This occurs both domestically as well as internationally. We derive the predictions of the model on how other sectors, as well as other countries R\&D investments should affect domestic productivity. Empirical results are presented employing data from thirteen manufacturing industries in eight OECD countries

\footnotetext{
${ }^{23}$ For the input-output specification, we have estimated a $\beta_{3}$ of about $23 \%$, see (T1.3).

${ }^{24}$ Coe and Helpman (1995), p.869, Table 3, (ii)). This comparison is even more striking if one takes into account that Coe and Helpman's specification (a) does not include year fixedeffects, and (b) their analysis uses country-level data. The former implies that their estimate is an upper bound of the 'true' effect, because without year effects, the regression is likely to pick up time trends. On point (b), the use of country-level data should lead to strong spillover effects, because at a country level of aggregation, productivity effects are internalized whereas they might be external effects at an industry level (see Griliches 1995). The result has to do with Coe and Helpman's specification, which is $\log$-linear: $\log f=\alpha+\kappa_{1} \log b+\kappa_{2} \log b^{f}+\varepsilon$. Using this specification in our context, we estimate an elasticity with respect to foreign R\&D in the same industry $\left(\kappa_{2}\right)$ of about $4 \%$, as opposed to $16 \%$. Given the model laid out above, however, the non-linear specification is preferred.
} 
over the period of 1970 to 1991.

The empirical analysis, first, confirms earlier findings that cumulative $R \& D$ expenditures investments are positively related to productivity levels, and we estimate an elasticity of TFP with respect to own-industry R\&D between $7 \%$ and 17\%. Secondly, the receiving industry's productivity level benefits, as predicted by the model, also from other industries' technology investments, an effect which is at least in part due to trade in embodied technology. We find that the benefit derived from foreign R\&D in the same industry is in the order of $50-95 \%$ of the productivity effect of own $R \& D$. These results are consistent with international trade being an important transmittent of foreign technology in the same industry.

For domestic interindustry technology flows, the results strongly suggest that trade in goods is not all what matters for technology transmission, as the results based on a technology flow matrix are preferred to results based only on the inputoutput structure of the economy. We estimate that domestic, outside-industry $\mathrm{R} \& \mathrm{D}$ is one-fifth to one-half as effective in raising productivity as own-industry R\&D. These results suggest that at the two- to three-digit industry level, industries benefit generally more from foreign technology creation in the same industry than from domestic technology creation in other industries. Our attempts to trace 
technology flows from other foreign sectors are largely unsuccessful: the estimates obtained in that respect are never very plausible. This question will have to be addressed by future work.

Some additional support for the notion that technology is transmitted in part through being embodied in goods which are traded at arm's length comes from considering different types of industries within the sample individually. First, we find that outside $R \& D$ is more important for sectors which are themselves not conducting much $R \& D$ on their own-as it should be, according to the embodied technology transmission hypothesis. Second, the finding that in $R \& D$ intensive industries, there is only a relatively small gain from foreign, same-industry R\&D is consistent with the notion that market conduct in these industries tends to be monopolistically competitive, with internalization of the return to the R\&D investment being a primary concern, and where there is therefore little trade of innovative products among competing firms.

Finally, it is important to note that this study has not addressed the important question of the extent to which technology transmission is embodied, relative to being disembodied. This is evidenced by the fact that we have not tried to estimate the technology flow matrix, computing the 'effective' $R \& D$ for a given 
sector, jointly with the relation between that 'effective' $R \& D$ and productivity. Estimating the channels of technology transmission, and quantifying the extent to which technology transmission is embodied (and disembodied) is therefore an important topic for future research. 
Table 1: Intersectoral Input-Output and International Trade Specification Dependent Variable: Log of TFP index; 2288 observations

\begin{tabular}{|c|c|c|c|c|}
\hline & (T1.1) & $(\mathrm{T} 1.2)$ & (T1.3) & (T1.4) \\
\hline $\begin{array}{c}\beta_{1} \text { : Same Sector, } \\
\text { Domestic R\&D (b) } \\
\text { (s.e.) }\end{array}$ & $\begin{array}{l}0.074^{* *} \\
(0.010)\end{array}$ & $\begin{array}{l}0.194^{* *} \\
(0.029)\end{array}$ & $\begin{array}{l}0.252^{* *} \\
(0.032)\end{array}$ & $\begin{array}{l}0.212^{* *} \\
(0.058)\end{array}$ \\
\hline $\begin{array}{c}\beta_{2} \text { : Other Sector, } \\
\text { Domestic R\&D }\left(b^{i o}\right) \\
\text { (s.e.) }\end{array}$ & & $\begin{array}{l}1.639^{* *} \\
(0.471)\end{array}$ & $\begin{array}{l}2.021^{* *} \\
(0.567)\end{array}$ & $\begin{array}{l}2.316^{* *} \\
(0.633)\end{array}$ \\
\hline $\begin{array}{c}\beta_{3}: \text { Same Sector, } \\
\text { Foreign } R \& D\left(b^{f}\right) \\
\text { (s.e.) }\end{array}$ & & & $\begin{array}{l}0.911^{* *} \\
(0.276)\end{array}$ & $\begin{array}{l}1.010^{* *} \\
(0.304)\end{array}$ \\
\hline $\begin{array}{c}\beta_{4} \text { : Other Sector, } \\
\text { Foreign R\&D }\left(b^{f, i o}\right) \\
\text { (s.e.) }\end{array}$ & & & & $\begin{array}{l}-0.885 \\
(0.773)\end{array}$ \\
\hline $\begin{array}{c}\text { F-statistic } \\
\text { (Degr. of freedom) }\end{array}$ & $\begin{array}{c}52.67 \\
(1,2286)\end{array}$ & $\begin{array}{c}37.14 \\
(2,2285)\end{array}$ & $\begin{array}{c}30.99 \\
(3,2284)\end{array}$ & $\begin{array}{c}23.79 \\
(4,2283)\end{array}$ \\
\hline $\bar{R}^{2}$ & 0.75 & 0.759 & 0.765 & 0.766 \\
\hline
\end{tabular}


Table 2: Technology Flow and International Trade Specification Dependent Variable: Log of TFP index; 2288 observations

\begin{tabular}{|c|c|c|c|c|}
\hline & $(\mathrm{T} 2.1)$ & $(\mathrm{T} 2.2)$ & (T2.3) & $(\mathrm{T} 2.4)$ \\
\hline $\begin{array}{c}\beta_{1} \text { : Same Sector, } \\
\text { Domestic R\&D (b) } \\
\text { (s.e.) }\end{array}$ & $\begin{array}{l}0.074^{* *} \\
(0.010)\end{array}$ & $\begin{array}{l}0.107^{* *} \\
(0.028)\end{array}$ & $\begin{array}{l}0.171^{* *} \\
(0.035)\end{array}$ & $\begin{array}{l}0.103^{* *} \\
(0.043)\end{array}$ \\
\hline $\begin{array}{c}\beta_{2}: \text { Other Sector, } \\
\text { Domestic R\&D }\left(b^{t m}\right) \\
\text { (s.e.) }\end{array}$ & & $\begin{array}{c}0.472 \\
(0.383)\end{array}$ & $\begin{array}{c}0.511 \\
(0.417)\end{array}$ & $\begin{array}{l}1.24^{* *} \\
(0.386)\end{array}$ \\
\hline $\begin{array}{c}\beta_{3} \text { : Same Sector, } \\
\text { Foreign R\&D }\left(b^{f}\right) \\
\text { (s.e.) }\end{array}$ & & & $\begin{array}{l}0.952^{* *} \\
(0.259)\end{array}$ & $\begin{array}{l}0.848^{* *} \\
(0.216)\end{array}$ \\
\hline $\begin{array}{c}\beta_{4} \text { : Other Sector, } \\
\text { Foreign R\&D }\left(b^{f, t m}\right) \\
\text { (s.e.) }\end{array}$ & & & & $\begin{array}{l}-1.808^{* *} \\
(0.498)\end{array}$ \\
\hline $\begin{array}{c}\text { F-statistic } \\
\text { (Degr. of freedom) }\end{array}$ & $\begin{array}{c}52.67 \\
(1,2286)\end{array}$ & $\begin{array}{c}26.02 \\
(2,2285)\end{array}$ & $\begin{array}{c}24.33 \\
(3,2284)\end{array}$ & $\begin{array}{c}24.62 \\
(4,2283)\end{array}$ \\
\hline $\bar{R}^{2}$ & 0.75 & 0.75 & 0.758 & 0.768 \\
\hline
\end{tabular}


Table 3: Technology Flow and International Trade Specification R\&D Intensive Industries

Dependent Variable: Log of TFP index; 2288 observations

\begin{tabular}{|c|c|c|c|c|}
\hline & (T3.1) & (T3.2) & (T3.3) & (T3.4) \\
\hline $\begin{array}{c}\beta_{1} \text { : Same Sector, } \\
\text { Domestic R\&D (b) } \\
\text { (s.e.) }\end{array}$ & $\begin{array}{l}0.442^{* *} \\
(0.040)\end{array}$ & $\begin{array}{l}0.513^{* *} \\
(0.054)\end{array}$ & $\begin{array}{l}0.730^{* *} \\
(0.068)\end{array}$ & $\begin{array}{l}0.443^{* *} \\
(0.093)\end{array}$ \\
\hline $\begin{array}{c}\beta_{2}: \text { Other Sector, } \\
\text { Domestic R\&D }\left(b^{t m}\right) \\
\text { (s.e.) }\end{array}$ & & $\begin{array}{l}0.192^{*} \\
(0.103)\end{array}$ & $\begin{array}{l}0.381^{* *} \\
(0.131)\end{array}$ & $\begin{array}{l}0.556^{* *} \\
(0.138)\end{array}$ \\
\hline $\begin{array}{l}\beta_{3}: \text { Same Sector, } \\
\text { Foreign R\&D }\left(b^{f}\right) \\
\text { (s.e.) }\end{array}$ & & & $\begin{array}{l}0.577^{* *} \\
(0.144)\end{array}$ & $\begin{array}{l}0.499^{* *} \\
(0.131)\end{array}$ \\
\hline $\begin{array}{c}\beta_{4}: \text { Other Sector, } \\
\text { Foreign } \mathrm{R} \& \mathrm{D}\left(b^{f, t m}\right) \\
\text { (s.e.) }\end{array}$ & & & & $\begin{array}{l}-0.882^{* *} \\
(0.192)\end{array}$ \\
\hline $\begin{array}{c}\text { F-statistic } \\
\text { (Degr. of freedom) }\end{array}$ & $\begin{array}{l}122.64 \\
(1,702)\end{array}$ & $\begin{array}{c}63.50 \\
(2,701)\end{array}$ & $\begin{array}{c}52.31 \\
(3,700)\end{array}$ & $\begin{array}{c}53.14 \\
(4,699)\end{array}$ \\
\hline
\end{tabular}




\section{References}

[1] Branstetter, L. (1996), "Are Knowledge Spillovers International or Intranational in Scope? Microeconometric Evidence from the U.S. and Japan", mimeo, Harvard University, August.

[2] Coe, D.T., and E. Helpman (1995), "International R\&D Spillovers", European Economic Review 39: 859-887.

[3] Coe, D.T., E. Helpman, and A.W. Hoffmaister (1995), "North-South R\&D Spillovers", CEPR Working Paper No.1133, London.

[4] Eaton, J., and S. Kortum (1996), "Trade in Ideas: Patenting and Productivity in the OECD", Journal of International Economics 40: 251-278.

[5] Englander, A., R. Evenson, and M. Hanazaki (1988), "R\&D, Innovation and the Total Factor Productivity Slowdown", OECD Economic Studies 11: 7-42.

[6] Ethier, W.J. (1982), "National and International Returns to Scale in the Modern Theory of International Trade", American Economic Review 72: 389405. 
[7] Fullerton, D., and M. Karayannis (1993), "United States", Chapter 10 in Jorgenson and Landau (1993a), pp.333-367.

[8] Griliches, Z. (1979), "Issues in Assessing the Contribution of Research and Development to Productivity Growth", Bell Journal of Economics 10: 92116.

[9] Griliches, Z. (1984), RED, Patents, and Productivity, (ed.), Chicago: The University of Chicago Press.

[10] Griliches, Z. (1992), "The Search for R\&D Spillovers", Scandinavian Journal of Economics 94: 29-47.

[11] Griliches, Z. (1995), "R\&D and Productivity: Econometric Results and Measurement Issues", in P.Stoneman (ed.), Handbook of the Economics of Innovation and Technological Change, Blackwell, Oxford, UK, pp.52-89.

[12] Griliches, Z., and F. Lichtenberg (1984a), "R\&D and Productivity Growth at the Industry Level: Is there Still a Relationship?", in Griliches (1984), pp.465-496. 
[13] Griliches, Z., and F. Lichtenberg (1984b), "Interindustry Technology Flows and Productivity Growth: A Reexamination", Review of Economics and Statistics 66: 324-329.

[14] Grossman, G., and E. Helpman (1991), Innovation and Growth in the World Economy, Cambridge, MA.: MIT Press.

[15] Hall, R.E. (1991), "Invariance Properties of Solow's Productivity Residual", in Diamond (ed.), Growth/Productivity/Employment, MIT Press, Cambridge, Ma., pp.71-112.

[16] Jaffe, A.B. (1986), "Technological Opportunity and Spillovers of R\&D: Evidence from Firms' Patents, Profits, and Market Value", American Economic Review 76: 984-1001.

[17] Johnson, D., R. E. Evenson, and C. DeBresson (1997), "Innovation and Invention in Canada", mimeographed, Yale University, February.

[18] Jorgenson, D.W. (1993), "Introduction and Summary", Chapter 1 in Jorgenson and Landau (1993a), pp.1-56.

[19] Jorgenson, D.W., and R. Landau (1993a), Tax Reform and the Cost of Capital, (eds.), The Brookings Institution, Washington, D.C. 
[20] Jorgenson, D.W., and R. Landau (1993b), "Appendix" in Jorgenson and Landau (1993a), pp.369-406.

[21] Keller, W. (1996), "Absorptive Capacity: On the Creation and Acquisition of Technology in Development", Journal of Development Economics 49: 199227.

[22] Kortum, S., and J. Putnam (1997), "Assigning Patents to Industries: Tests of the Yale Technology Concordance", mimeographed, Boston University, January.

[23] Langer, C. (1986), World Trade and Production. Methodology and Tables in ISIC, Hamburg: Verlag Weltarchiv.

[24] Mansfield, E. (1984), "Comment" on the paper by Scherer, in Griliches (1984), pp. 461-464.

[25] Nadiri, M. I. (1993), "Innovations and Technological Spillovers", NBER Working Paper No. 4423, Cambridge, MA.

[26] Nadiri, M.I., and I.R. Prucha (1993), "Estimation of the Depreciation Rate of Physical and R\&D Capital in the U.S. Total Manufacturing Sector", NBER Working Paper No. 4591, Cambridge, MA. 
[27] OECD (1991), Basic Science and Technology Statistics, various years, OECD, Paris.

[28] OECD (1994), STAN Database for Industrial Analysis, OECD, Paris.

[29] Pakes, A., and M. Schankerman (1984), "The Rate of Obsolescence of Patents, Research Gestation Lags, and the Private Rate of Return to Research Resources", in Griliches (1984), pp.73-88.

[30] Park, W. (1995), "International R\&D Spillovers and OECD Economic Growth", Economic Inquiry 33: 571-591.

[31] Rivera-Batiz, L., and P.M. Romer (1991), "Economic Integration and Endogenous Growth", Quarterly Journal of Economics CVI: 531-555.

[32] Rodrik, D. (1995), "Trade and Industrial Policy Reform", in J. Behrman and T.N. Srinivasan (eds.) Handbook of Development Economics, Vol.III, Amsterdam: North Holland.

[33] Romer, P.M. (1990), "Endogenous Technological Change", Journal of Political Economy 98: S71-S102. 
[34] Scherer, F.M. (1984), "Using Linked Patent and R\&D Data to Measure Interindustry Technology Flows'", in Griliches (1984), pp. 417-461.

[35] Terleckyj, N.E. (1974), "Effects of R\&D on the Productivity Growth of Industries: An Exploratory Study", Washington, D.C.: National Planning Association.

[36] U.S. Department of Commerce (1991), "Benchmark Input-Output Accounts for the U.S. Economy, 1982", Survey of Current Business, July: 30-71.

[37] Wolff, E.N., and M.I. Nadiri (1993), "Spillover Effects, Linkage Structure, and Research and Development", Structural Change and Economic Dynamics 4: $315-331$.

[38] World Bank (1987), World Development Report 1987, New York: Oxford University Press for the World Bank. 


\section{A. Labor, physical capital, and gross production}

Data on these variables comes from the OECD (1994) STAN database. It provides internationally comparable data on industrial activity by sectors, primarily for OECD countries. The STAN figures are not submitted by the OECD member countries, but based on estimates by the OECD, which tries to ensure greater international comparability. See OECD (1994) for the details on adjustments of national data.

In constructing the TFP variable, we consider only inputs of labor and physical capital. Data on labor inputs $l$ can be extracted directly from the STAN databasethe number of workers engaged. This includes employees as well as the selfemployed, owner proprietors and unpaid family workers. The physical capital stock data is not available in that data base, but gross fixed capital formation in current prices is. We first convert the sectoral investment flows into constant 1985 prices. The deflators used for that are output deflators, because sectoral investment goods deflators were unavailable for this study. The capital stocks are then estimated using the perpetual inventory method, with-suppressing the 
industry subscripts-

$$
\begin{aligned}
& k_{i t}=\left(1-\delta_{i}\right) k_{i t-1}+i n v_{t-1}, \text { for } t=2, \ldots, 22, i=1, \ldots, 8 \\
& \text { and } \\
& k_{i 1}= \\
& \quad \frac{i n v_{i 1}}{\left(g_{i}+\delta_{i}\right)}, i=1, \ldots, 8,
\end{aligned}
$$

where inv is gross fixed capital formation in constant prices (land, buildings, machinery and equipment), $g$ is the average annual growth rate of $i n v$ over the period 1970-1991, and $\delta$ is the rate of depreciation. Country-specific depreciation rates are used, taken from Jorgenson and Landau (1993b), Table A-3:

$\begin{array}{ll}\text { Canada: } 8.51 \% & \text { Japan: } 6.6 \% \\ \text { France: } 17.39 \% & \text { Sweden: } 7.7 \% \\ \text { Germany: } 17.4 \% & \text { United Kingdom: } 8.19 \% \\ \text { Italy: } 11.9 \% & \text { United States: } 13.31 \%\end{array}$

The numbers, which are used throughout, are estimates for machinery \& manufacturing in the year 1980.

The parameter $\alpha_{i j t}$ is the share of the labor in total production costs. Following 
the approach by Hall (1991), the $\alpha_{i j t}$ 's are not calculated as the ratio of total labor compensation to value added (the revenue-based factor shares), but as costbased factor shares, which are robust in the presence of imperfect competition. For this we use the framework of the integrated capital taxation model of King and Fullerton (see Jorgenson 1993 and Fullerton and Karayannis 1993) and data provided in Jorgenson and Landau (1993b). The effective marginal corporate tax rate $\tau$ is given by the wedge between before-tax $(p)$ and after-tax rate of return $(\rho)$, relative to the former

$$
\tau=\frac{p-\rho}{p}
$$

Here, the variable of interest is $p$, the user cost of capital. It will be a function of the statutory marginal tax rate on corporate income, available investment tax credits, the rates of depreciation, and other influences.

In the case of equity financing, the after-tax rate of return will be $\rho=\chi+\varsigma$, where $\chi$ is the real interest rate, and $\varsigma$ is the rate of inflation. Jorgenson (1993) tabulates the values for the marginal effective corporate tax rate, $\tau$, in Table 1-1. According to the "fixed-r" strategy, one gives as an input a real interest rate $\chi$ and deduces $\tau$. In this case, we use a value of $\chi=0.1$, which, together with the actual values of $\varsigma$ allows, using equation (A.2) to infer the user cost of capital, $p$. 
From Jorgenson's Table 1-1 on $\tau$, we use the values on "manufacturing" (the 1980 values given are used for 1970-1982 in the sample, the 1985 values for 1983-1986, and Jorgenson's 1990 values are used for 1987-1991). This certainly introduces an error; in addition, the Jorgenson Table 1-1 is derived from a "fixed-p" approach, as opposed to the "fixed-r" approach employed here. Further, the results depend on the chosen real interest rate, $\tau$ varies by asset type, and $\rho$ is a function of the way of financing (equity versus debt primarily). Hence, there are, due to unavailability of more detailed data, several shortcomings in the construction of the cost-based factor shares. However, the chapter by Fullerton and Karayannis (1993) presents a sensitivity analysis in certain dimensions. Second, limited experiments with different values for $\chi$, the real interest rate, indicate that the basic results presented above do not depend on a particular value for $\chi$. Finally, the cost-based approach has the advantage of using all data on the user cost of capital compiled in Jorgenson and Landau (1993a) while at the same time being robust to deviations from perfect competition.

Having obtained the series on the user cost of capital and capital stock data, $\alpha$ is given by

$$
\alpha=\frac{w l}{w l+p k}
$$


where $w l$ are the constant price labor costs. Labor and capital inputs together with the factor shares allow to construct a Thornqvist index of total inputs $I_{t}$

$$
\begin{aligned}
\ln \left(\frac{I_{i j t}}{I_{i j t-1}}\right) & =\frac{1}{2} *\left[\alpha_{i j t}+\alpha_{i j t-1}\right] \ln \left(\frac{l_{i j t}}{l_{i j t-1}}\right) \\
& +\frac{1}{2} *\left[\left(1-\alpha_{i j t}\right)+\left(1-\alpha_{i j t-1}\right)\right] \ln \left(\frac{k_{i j t}}{k_{i j t-1}}\right) .
\end{aligned}
$$

This gives a series of growth of total factor input. The TFP growth series is obtained by subtracting total input from output growth. A value of 100 in 1970 is chosen for each of the $8 \times 13$ time series, for all industries $j$ and countries $i$.

\section{B. Data on R\&D}

The raw data on R\&D expenditures comes from OECD (1991). It is more patchy than the series on output, investment, and employment. This is not so much a problem of the sectoral breakdown, because the national statistical offices do collect their R\&D data along the lines of the two- or three-digit ISIC classification. But R\&D surveys were not conducted annually in all countries over the entire sample period. In the United Kingdom, for instance, they were held only every third year until well into the 1980s. In Germany, R\&D data is collected only biannually. Estimates of about $25 \%$ of all the R\&D expenditure data were obtained 
by interpolation.

The construction of the technology stock variables $n$ is based on data on total business enterprise intramural expenditure on $\mathrm{R} \& \mathrm{D}(\phi)$, in constant 1985 US $\$$, and it uses the OECD purchasing power parity rates for conversion. The OECD code for this series is BERD, given in Table 9B of OECD (1991). Also here, we use the perpetual inventory method to construct technology stocks, assuming that (industry and country subscripts are suppressed)

$$
\begin{aligned}
n_{t} & =(1-\delta) n_{t-1}+\phi_{t-1}, \text { for } t=2, \ldots, 22 \\
& \text { and } \\
n_{1}= & \frac{\phi_{1}}{(\lambda+\delta+0.1)} .
\end{aligned}
$$

The rate of depreciation of the knowledge stock, $\delta$, is set at 0.1 , and $\lambda$ is the average annual growth rate of $n$ over the period of $1970-1991 .{ }^{25}$ A higher (lower) choice of $\delta$ reduces (increases) the rate of growth of the knowledge stock over the period of observation. Nadiri and Prucha (1993) estimate $\delta$, and obtain a value of 0.12; earlier estimates by Pakes and Schankerman (1984) implied a $\delta$ of 0.25 (see the survey in Nadiri and Prucha 1993). Given that the data available for

\footnotetext{
${ }^{25}$ The denominator in the calculation of $n_{1}$ is increased by 0.1 in order to obtain positive estimates of $n_{1}$ throughout.
} 
this study does not permit a good estimate of $\delta$, we present a limited sensitivity analysis for alternative values of $\delta$ in Table A.7.

\section{Data on Import Flows, Input-Output Relations, and the Technology Flow Matrix}

Data on import flows for 1972, and 1975-91, in ISIC format, comes from the HWWA institute in Hamburg. The HWWA data base, in turn, relies on UN Commodity Trade Statistics, up to 1981, and the OECD Foreign Trade by Commodities Statistics, from 1982 onward. Because this data originally is in the Standard International Trade Classification (SITC) of the United Nations, a conversion to the ISIC scheme is necessary. We implicitly use the HWWA conversion scheme; it takes account of the three revisions the SITC classification has been undergoing during the period of observation. Langer (1986) describes the HWWA conversion from SITC to ISIC in some detail, and also shows that the differences to the OECD's conversion scheme are minor. Bilateral import shares are formed for all thirteen industries and eight countries, and a subset of them are reported in Table A.3-1 and A.3-2. We employ time-invariant bilateral import shares in the construction of the variables $b^{f}, b^{f, i o}$, and $b^{f, t m}$; these import shares are calculated 
as the average over the year 1972 and 1975-91.

The sources of the economy-wide input-output relations are for the year 1980, from U.S. Department of Commerce (1991). The input-output table for imports was not available for 1980; therefore, it has been derived from 1987 data, and draws on unpublished data as described in the text. The input-output matrix is given in Table A.4, and import input-output matrix is given in Table A.5. The technology flow matrix employed in this paper is based on the Yale Technology Concordance, the construction of which is described in detail in Evenson et al. (1991). The Yale Technology Concordance is based on more than 180,000 individual patent classifications at a 4-digit SIC level by the Canadian Intellectual Property Rights Office over the years of 1978-87. The concordance has been updated in the meantime; see Kortum and Putnam (1997) for tests of the patent assignments of the Yale Technology Concordance, and Johnson, Evenson, and DeBresson (1997) for a comparison of patents by industry as assigned by the Canadian Intellectual Property Office and industry-level data from innovation surveys. The $13 \times 13$ industry technology flow matrix TM is shown in Table A.6. 


\begin{tabular}{|c|c|c|c|c|c|c|c|c|c|}
\hline \multicolumn{10}{|c|}{$\begin{array}{l}\text { Total Factor Productivity Index Summary Statistics } \\
\text { By Industry and By Country }\end{array}$} \\
\hline ISIC & 1970 & 1980 & 1991 & $\begin{array}{c}\text { Average } \\
\text { Annual } \\
\text { Growth } \\
1970-91(\%)\end{array}$ & & 1970 & 1980 & 1991 & $\begin{array}{c}\text { Average } \\
\text { Annual } \\
\text { Growth } \\
\text { 1970-91(\%) }\end{array}$ \\
\hline 31 & 800 & 1056.6 & 982.0 & 1.0 & CAN & 1300 & 1837.4 & 1990.3 & 2.0 \\
\hline 32 & 800 & 1070.6 & 1290.0 & 2.3 & FRA & 1300 & 2405.1 & 2871.7 & 3.8 \\
\hline 33 & 800 & 1044.7 & 1206.8 & 2.0 & GER & 1300 & 1927.8 & 2221.5 & 2.6 \\
\hline 34 & 800 & 1004.0 & 1138.0 & 1.7 & IT & 1300 & 2058.0 & 3372.0 & 4.5 \\
\hline $351 / 2$ & 800 & 1376.6 & 1768.5 & 3.8 & JAP & 1300 & 2398.4 & 2892.5 & 3.8 \\
\hline $353 / 4$ & 800 & 2014.2 & 1958.3 & 4.3 & SWE & 1300 & 1936.5 & 1836.9 & 1.6 \\
\hline $355 / 6$ & 800 & 1158.4 & 1346.4 & 2.5 & UK & 1300 & 1513.4 & 2220.0 & 2.5 \\
\hline 36 & 800 & 1084.6 & 1356.2 & 2.5 & USA & 1300 & 1641.6 & 1978.2 & 2.0 \\
\hline 37 & 800 & 1150.5 & 1516.7 & 3.0 & & & & & \\
\hline 381 & 800 & 1046.8 & 1182.8 & 1.9 & & & & & \\
\hline $382 / 5$ & 800 & 1261.4 & 1967.0 & 4.3 & & & & & \\
\hline 383 & 800 & 1323.1 & 2093.4 & 4.6 & & & & & \\
\hline 384 & 800 & 1126.7 & 1577.1 & 3.2 & & & & & \\
\hline
\end{tabular}




\begin{tabular}{|l|c|c|c|c||c|c|c|c|c|}
\hline \multicolumn{8}{|c|}{$\begin{array}{l}\text { Table A.2 } \\
\text { R\&D Stock Summary Statistics } \\
\text { Bndustry and By Country; 1985 US } \$\end{array}$} \\
\hline \hline ISIC & 1970 & 1980 & 1991 & $\begin{array}{c}\text { Average } \\
\text { Annual } \\
\text { Growth } \\
1970-91(\%)\end{array}$ & & 1970 & 1980 & 1991 & $\begin{array}{c}\text { Average } \\
\text { Annual } \\
\text { Growth } \\
1970-91(\%)\end{array}$ \\
\hline 31 & 6390.7 & 15424.7 & 30092.5 & 7.4 & CAN & 4930.9 & 10435.5 & 22820.6 & 7.3 \\
\hline 32 & 4744.6 & 7482.3 & 9816.1 & 3.5 & FRA & 25216.9 & 60913.3 & 112246.8 & 7.1 \\
\hline 33 & 1794.4 & 3211.0 & 4798.0 & 4.7 & GER & 41545.6 & 98871.5 & 193959.4 & 7.3 \\
\hline 34 & 4112.3 & 9058.7 & 14966.6 & 6.2 & IT & 7807.3 & 19329.5 & 45193.6 & 8.4 \\
\hline $351 / 2$ & 55698.7 & 133493.4 & 259920.6 & 7.3 & JAP & 37341.0 & 106730.8 & 284083.3 & 9.7 \\
\hline $353 / 4$ & 11104.7 & 22640.8 & 37347.5 & 5.8 & SWE & 6674.0 & 15234.3 & 25765.8 & 6.4 \\
\hline $355 / 6$ & 6757.1 & 16073.8 & 29553.5 & 7.0 & UK & 39067.6 & 76971.6 & 121302.8 & 5.4 \\
\hline 36 & 5080.6 & 11319.5 & 23585.0 & 7.3 & USA & 248541.0 & 517898.8 & 950958.3 & 6.4 \\
\hline 37 & 13472.5 & 26591.0 & 41960.1 & 5.4 & & & & & \\
\hline 381 & 5115.6 & 11939.9 & 23450.6 & 7.3 & & & & & \\
\hline $382 / 5$ & 48366.7 & 131.561 .1 & 303919.1 & 8.8 & & & & & \\
\hline 383 & 104071.0 & 221154.1 & 425524.1 & 6.7 & & & & & \\
\hline 384 & 14415.7 & 296435.0 & 551396.9 & 6.4 & & & & & \\
\hline
\end{tabular}


Table A.3-1

Bilateral Import Shares in Food, Beverages \& Tobacco Manufacturing (ISIC 31) Average over 1972-1991; in per cent

\begin{tabular}{|l|c|c|c|c|c|c|c|c}
\hline \hline from / to & CAN & FRA & GER & IT & JAP & SWE & UK & USA \\
\hline CAN & 0 & 1.93 & 1.4 & 0.67 & 14.46 & 3.87 & 7.07 & 35.2 \\
\hline FRA & 8.33 & 0 & 48.95 & 39.4 & 6.6 & 17.13 & 35.78 & 17.5 \\
\hline GER & 3.37 & 36.69 & 0 & 45.97 & 3.64 & 30.24 & 25.09 & 9.24 \\
\hline IT & 3.6 & 24.99 & 22.96 & 0 & 0.98 & 7.78 & 15.03 & 12.26 \\
\hline JAP & 2.6 & 0.53 & 1.14 & 0.14 & 0 & 0.57 & 2.16 & 5.84 \\
\hline SWE & 2.0 & 0.66 & 1.35 & 0.89 & 2.23 & 0 & 1.5 & 1.54 \\
\hline UK & 7.8 & 21.74 & 8.94 & 6.07 & 7.53 & 20.46 & 0 & 18.43 \\
\hline USA & 74.63 & 13.46 & 15.26 & 6.86 & 65.46 & 19.95 & 13.37 & 0 \\
\hline
\end{tabular}


Table A.3-2

Bilateral Import Shares in Transportation Equipment (ISIC 384)

Average over 1972-1991; in per cent

\begin{tabular}{|l|c|c|c|c|c|c|c|c}
\hline \hline from / to & CAN & FRA & GER & IT & JAP & SWE & UK & USA \\
\hline CAN & 0 & 0.5 & 0.38 & 0.37 & 0.79 & 0.83 & 1.02 & 38.22 \\
\hline FRA & 0.74 & 0 & 43.57 & 34.79 & 3.51 & 8.25 & 18.52 & 3.41 \\
\hline GER & 2.06 & 43.93 & 0 & 44.37 & 23.77 & 47.77 & 40.94 & 12.44 \\
\hline IT & 0.23 & 17.38 & 13.31 & 0 & 1.96 & 3.49 & 6.64 & 1.69 \\
\hline JAP & 7.26 & 7.05 & 15.04 & 2.09 & 0 & 13.94 & 13.85 & 37.26 \\
\hline SWE & 0.53 & 2.95 & 2.11 & 2.02 & 4.24 & 0 & 6.11 & 2.29 \\
\hline UK & 1.27 & 9.72 & 12.77 & 7.61 & 6.59 & 12.84 & 0 & 4.7 \\
\hline USA & 87.9 & 18.47 & 12.82 & 8.75 & 61.63 & 12.88 & 12.91 & 0 \\
\hline
\end{tabular}


Table A. 4

Economy-wide Input-Output Relations

U.S. economy, 1980; $13 \times 13$ ISIC industries

Share of total intermediate inputs of column industry from row industry; in percent

$\begin{array}{lccccccccccccc} & 31 & 32 & 33 & 34 & 351 / 2 & 353 / 4 & 355 / 6 & 36 & 37 & 381 & 382 / 5 & 383 & 384 \\ 31 & 0 & 0.81 & 0.07 & 0.32 & 0.84 & 0.1 & 0.02 & 0.07 & 0.01 & 0.01 & 0.06 & 0.01 & 0.01 \\ 32 & 0.04 & 0 & 3.45 & 1.02 & 0.14 & 0.02 & 4.71 & 0.4 & 0.04 & 0.13 & 0.67 & 0.1 & 2.07 \\ 33 & 0.05 & 0.12 & 0 & 4.8 & 0.08 & 0.03 & 0.41 & 1.13 & 0.28 & 0.49 & 0.39 & 0.75 & 1.27 \\ 34 & 4.78 & 1.22 & 1.23 & 0 & 3.29 & 0.27 & 3.77 & 4.87 & 0.26 & 1.45 & 1.51 & 1.76 & 0.31 \\ 351 / 2 & 1.74 & 14.96 & 2.25 & 7.52 & 0 & 3.23 & 42.31 & 9.91 & 5.19 & 2.04 & 1.07 & 3.9 & 0.68 \\ 353 / 4 & 0.63 & 1.36 & 3.58 & 3.73 & 4.1 & 0 & 1.57 & 2.86 & 2.04 & 2.04 & 1.49 & 1.21 & 1.5 \\ 355 / 6 & 1.92 & 1.98 & 2.54 & 2.39 & 3.35 & 0.18 & 0 & 1.03 & 0.7 & 1.49 & 3.63 & 5.81 & 4.22 \\ 36 & 1.96 & 0.27 & 0.82 & 0.12 & 0.83 & 0.24 & 1.28 & 0 & 0.74 & 1.01 & 1.26 & 1.76 & 1.23 \\ 37 & 0 & 0.01 & 3.68 & 0.31 & 0.62 & 0.08 & 0.8 & 1 & 0 & 43.16 & 16.44 & 11.76 & 10.51 \\ 381 & 4.68 & 0.12 & 6.29 & 0.83 & 2.51 & 0.56 & 2.53 & 1.74 & 1.62 & 0 & 8.2 & 6.39 & 10.67 \\ 382 / 5 & 0.26 & 0.92 & 1.41 & 1.18 & 1.23 & 0.05 & 1.34 & 1.63 & 3.31 & 4.51 & 0 & 2.78 & 7.68 \\ 383 & 0.01 & 0.04 & 0.18 & 0.03 & 0.05 & 0.01 & 0.34 & 0.28 & 0.91 & 1.48 & 10.58 & 0 & 4.67 \\ 384 & 0.01 & 0.03 & 0.07 & 0.08 & 0.02 & 0.02 & 0.03 & 0.04 & 0.03 & 0.08 & 0.0214 & 0.07 & 0\end{array}$

Table A.5

Import Input-Output Relations

U.S. economy, $1987 ; 13 \times 13$ ISIC industries

Share of total intermediate inputs of column industry from row industry; in percent

\begin{tabular}{|c|c|c|c|c|c|c|c|c|c|c|c|c|c|}
\hline & 31 & 32 & 33 & 34 & $351 / 2$ & $353 / 4$ & $355 / 6$ & 36 & 37 & 381 & $382 / 5$ & 383 & 384 \\
\hline 31 & 0 & 0.45 & 0.01 & 0.24 & 0.6 & 0.03 & 0.03 & 0.08 & 0.01 & 0 & 0.05 & 0.01 & 0 \\
\hline 32 & 0.06 & 0 & 7.77 & 1.04 & 0.14 & 0.03 & 2.97 & 0.97 & 0.04 & 0.03 & 0.28 & 0.11 & 1.88 \\
\hline 33 & 0.06 & 0.3 & 0 & 0.46 & 0.03 & 0.04 & 0.57 & 2.27 & 0.23 & 0.53 & 0.23 & 0.31 & 3.22 \\
\hline 34 & 1.34 & 0.39 & 0.29 & 0 & 2.49 & 0.01 & 3.02 & 3.45 & 0.04 & 0.23 & 0.27 & 0.49 & 0.04 \\
\hline $351 / 2$ & 3.45 & 11.7 & 3.31 & 6.98 & 0 & 2.04 & 41.74 & 17.69 & 4.17 & 1.46 & 0.62 & 2.6 & 0.32 \\
\hline $353 / 4$ & 0.43 & 0.46 & 1.29 & 1.84 & 1.35 & 0 & 0.82 & 1.7 & 0.89 & 1.52 & 0.21 & 0.3 & 0.17 \\
\hline $355 / 6$ & 2.01 & 2.56 & 7.16 & 2.24 & 2.38 & 0.2 & 0 & 0.41 & 0.54 & 3.97 & 2.84 & 3.64 & 2.99 \\
\hline 36 & 0.41 & 0.11 & 1.84 & 0.05 & 0.76 & 0.03 & 1.15 & 0 & 1.31 & 1.36 & 0.73 & 1.72 & 0.91 \\
\hline 37 & 0.01 & 0.01 & 6.53 & 0.26 & 0.25 & 0.01 & 1.3 & 3.76 & 0 & 67.32 & 8.48 & 14.32 & 3.82 \\
\hline 381 & 1.34 & 0.09 & 11.01 & 1.03 & 2.54 & 0.34 & 5.35 & 1.24 & 1.5 & 0 & 4.71 & 3.68 & 6.48 \\
\hline $382 / 5$ & 0.63 & 3.77 & 2.5 & 4.36 & 2.3 & 0.04 & 3.44 & 1.74 & 4.29 & 4.67 & 0 & 6.37 & 7.27 \\
\hline 383 & 0.02 & 0.05 & 2.42 & 0.16 & 0.09 & 0.01 & 1.67 & 1.16 & 1.83 & 2.51 & 23.79 & 0 & 12.32 \\
\hline 384 & 0.04 & 0.03 & 1.14 & 0.17 & 0.03 & 0.03 & 0.08 & 0.14 & 0.05 & 0.17 & 0.08 & 0.04 & 0 \\
\hline
\end{tabular}




\begin{tabular}{|l|c|c|c|c|c|c|c|c|c|c|c|c|c|c|}
\hline \multicolumn{10}{|c|}{ Table A.6 } \\
\multicolumn{10}{|c|}{ Technology Flow Matrix } \\
\hline \hline & 31 & 32 & 33 & 34 & $351 / 2$ & $353 / 4$ & $355 / 6$ & 36 & 37 & 381 & $382 / 5$ & 383 & 384 \\
\hline 31 & 97.6 & 0.3 & 0.0 & 0.3 & 1.2 & 0.0 & 0.1 & 0.0 & 0.0 & 0.4 & 0.0 & 0.0 & 0.0 \\
\hline 32 & 0.7 & 66.8 & 1.1 & 2.5 & 0.9 & 0.2 & 1.6 & 1.0 & 0.1 & 0.5 & 3.7 & 17.7 & 3.1 \\
\hline 33 & 1.7 & 0.6 & 82.6 & 0.6 & 0.6 & 0.0 & 0.0 & 0.0 & 0.2 & 0.4 & 3.3 & 2.3 & 7.7 \\
\hline 34 & 26.0 & 2.7 & 1.0 & 57.7 & 2.6 & 0.3 & 1.4 & 0.5 & 0.0 & 1.3 & 4.0 & 2.1 & 0.2 \\
\hline $351 / 2$ & 1.6 & 2.8 & 0.6 & 2.6 & 70.3 & 2.1 & 9.0 & 0.7 & 0.7 & 3.3 & 3.2 & 2.2 & 0.9 \\
\hline $353 / 4$ & 0.3 & 2.0 & 0.0 & 1.0 & 4.3 & 35.8 & 0.8 & 0.8 & 3.0 & 5.5 & 17.8 & 2.8 & 26.1 \\
\hline $355 / 6$ & 7.8 & 2.2 & 1.8 & 1.9 & 7.3 & 0.3 & 49.1 & 1.0 & 0.2 & 3.1 & 5.4 & 3.7 & 16.1 \\
\hline 36 & 0.9 & 1.0 & 0.5 & 0.2 & 2.1 & 0.6 & 0.4 & 59.1 & 7.7 & 5.2 & 7.3 & 11.9 & 3.2 \\
\hline 37 & 0.0 & 0.2 & 0.3 & 0.2 & 2.6 & 0.4 & 0.4 & 0.2 & 47.0 & 19.9 & 10.5 & 10.5 & 7.7 \\
\hline 381 & 2.2 & 1.4 & 4.8 & 0.6 & 1.5 & 0.7 & 2.6 & 1.6 & 3.3 & 42.1 & 29.4 & 3.2 & 6.4 \\
\hline $382 / 5$ & 4.5 & 3.2 & 1.4 & 7.4 & 5.3 & 1.9 & 4.9 & 2.6 & 6.0 & 5.5 & 49.1 & 4.1 & 4.0 \\
\hline 383 & 0.1 & 0.1 & 0.1 & 0.2 & 0.5 & 0.0 & 0.1 & 0.1 & 0.6 & 1.5 & 13.1 & 79.5 & 3.9 \\
\hline 384 & 0.0 & 0.0 & 0.1 & 0.0 & 0.1 & 0.0 & 0.1 & 0.0 & 0.0 & 0.0 & 0.7 & 0.0 & 98.9 \\
\hline
\end{tabular}


Table A.7-1

Sensitivity Analysis: Timing and Knowledge Depreciation Rate All Industries; Dependent Variable: Log of TFP index

\begin{tabular}{|c|c|c|c|c|}
\hline \multicolumn{5}{|c|}{ All regressors } \\
\hline & & Timing & Knowledge & eciation Rate \\
\hline & (T2.4) & $\begin{array}{c}\text { Foreign } \mathrm{R} \& \mathrm{D}\left(b^{f}, b^{f, t m}\right) \\
\text { lagged by one period }\end{array}$ & $\delta=0$ & $\delta=0.2$ \\
\hline $\begin{array}{c}\beta_{1} \text { : Same Sector, } \\
\text { Domestic R\&D (b) } \\
\text { (s.e.) }\end{array}$ & $\begin{array}{l}0.102^{* *} \\
(0.043)\end{array}$ & $\begin{array}{l}0.097^{* *} \\
(0.045)\end{array}$ & $\begin{array}{l}0.152^{* *} \\
(0.069)\end{array}$ & $\begin{array}{l}0.109^{* *} \\
(0.051)\end{array}$ \\
\hline $\begin{array}{c}\beta_{2}: \text { Other Sector, } \\
\text { Domestic R\&D }\left(b^{t m}\right) \\
\text { (s.e.) }\end{array}$ & $\begin{array}{l}1.235^{* *} \\
(0.386)\end{array}$ & $\begin{array}{l}0.655^{* *} \\
(0.354)\end{array}$ & $\begin{array}{l}1.024^{* *} \\
(0.364)\end{array}$ & $\begin{array}{c}0.323 \\
(0.354)\end{array}$ \\
\hline $\begin{array}{c}\beta_{3}: \text { Same Sector, } \\
\text { Foreign R\&D }\left(b^{f}\right) \\
\text { (s.e.) }\end{array}$ & $\begin{array}{l}0.848^{* *} \\
(0.216)\end{array}$ & $\begin{array}{l}0.812^{* *} \\
(0.218)\end{array}$ & $\begin{array}{l}1.034^{* *} \\
(0.245)\end{array}$ & $\begin{array}{l}0.956^{* *} \\
(0.312)\end{array}$ \\
\hline $\begin{array}{c}\beta_{4} \text { : Other Sector, } \\
\text { Foreign R\&D }\left(b^{f, t m}\right) \\
\text { (s.e.) }\end{array}$ & $\begin{array}{c}-1.808^{* *} \\
(0.498)\end{array}$ & $\begin{array}{c}-1.294^{* *} \\
(0.516)\end{array}$ & $\begin{array}{c}-1.733^{* *} \\
(0.549)\end{array}$ & $\begin{array}{l}-0.902 \\
(0.598)\end{array}$ \\
\hline $\begin{array}{c}\text { F-statistic } \\
\text { (Degr. of freedom) }\end{array}$ & $\begin{array}{c}24.61 \\
(4,2283)\end{array}$ & $\begin{array}{c}20.70 \\
(4,2179)\end{array}$ & $\begin{array}{c}23.25 \\
(4,2283)\end{array}$ & $\begin{array}{c}21.47 \\
(4,2283)\end{array}$ \\
\hline $\begin{array}{l}\text { Number of } \\
\text { Observations }\end{array}$ & 2288 & 2184 & 2288 & 2288 \\
\hline
\end{tabular}


Table A.7-2

Sensitivity Analysis: Timing and Knowledge Depreciation Rate

All Industries; Dependent Variable: Log of TFP index; variable $b^{f, t m}$ excluded

\begin{tabular}{|c|c|c|c|c|}
\hline \multicolumn{5}{|c|}{ Variable $b^{f, t m}$ excluded } \\
\hline & $\begin{array}{l}\text { Benchmark } \\
\text { as in text }\end{array}$ & Timing & $\begin{array}{r}\mathrm{K} \\
\text { Depre }\end{array}$ & $\begin{array}{l}\text { ledge } \\
\text { tion Rate }\end{array}$ \\
\hline & $(\mathrm{T} 2.3)$ & $\begin{array}{c}\text { Foreign } \mathrm{R} \& \mathrm{D}\left(b^{f}, b^{f, t m}\right) \\
\text { lagged by one period }\end{array}$ & $\delta=0$ & $\delta=0.2$ \\
\hline $\begin{array}{c}\beta_{1} \text { : Same Sector, } \\
\text { Domestic R\&D (b) } \\
\text { (s.e.) }\end{array}$ & $\begin{array}{l}0.171^{* *} \\
(0.033)\end{array}$ & $\begin{array}{l}0.150^{* *} \\
(0.035)\end{array}$ & $\begin{array}{l}0.233^{* *} \\
(0.049)\end{array}$ & $\begin{array}{l}0.137^{* *} \\
(0.034)\end{array}$ \\
\hline $\begin{array}{c}\beta_{2}: \text { Other Sector, } \\
\text { Domestic R\&D }\left(b^{t m}\right) \\
\text { (s.e.) }\end{array}$ & $\begin{array}{r}0.551 \\
(0.417)\end{array}$ & $\begin{array}{r}0.235 \\
(0.428)\end{array}$ & $\begin{array}{l}0.691^{*} \\
(0.419)\end{array}$ & $\begin{array}{c}-0.7 \times 10^{-3} \\
(0.415)\end{array}$ \\
\hline $\begin{array}{c}\beta_{3}: \text { Same Sector, } \\
\text { Foreign } \mathrm{R} \& \mathrm{D}\left(b^{f}\right) \\
\text { (s.e.) }\end{array}$ & $\begin{array}{l}0.952^{* *} \\
(0.259)\end{array}$ & $\begin{array}{l}0.959^{* *} \\
(0.277)\end{array}$ & $\begin{array}{l}0.699^{* *} \\
(0.260)\end{array}$ & $\begin{array}{l}0.947^{* *} \\
(0.263)\end{array}$ \\
\hline $\begin{array}{c}\text { F-statistic } \\
\text { (Degr. of freedom) }\end{array}$ & $\begin{array}{c}24.33 \\
(3,2284)\end{array}$ & $\begin{array}{c}23.00 \\
(3,2180)\end{array}$ & $\begin{array}{c}20.51 \\
(3,2284)\end{array}$ & $\begin{array}{c}25.02 \\
(3,2284)\end{array}$ \\
\hline $\begin{array}{l}\text { Number of } \\
\text { Observations }\end{array}$ & 2288 & 2184 & 2288 & 2288 \\
\hline
\end{tabular}




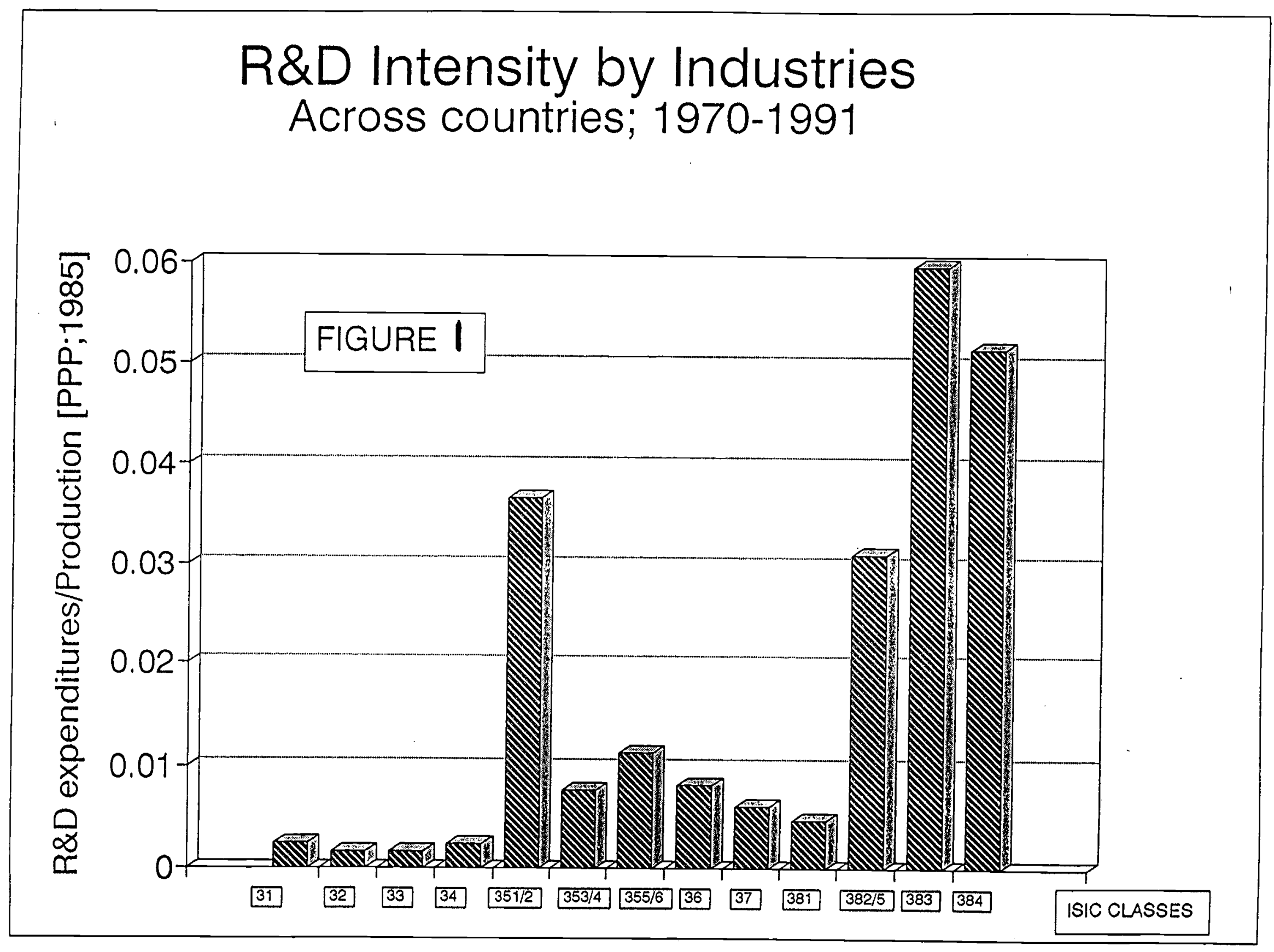

